\title{
Issue salience in the European Policy Process: what impact on transposition?
}

Citation for published version (APA):

Spendzharova, A., \& Versluis, E. (2013). Issue salience in the European Policy Process: what impact on transposition? Journal of European Public Policy, 20(10), 1499-1516.

https://doi.org/10.1080/13501763.2013.781802

Document status and date:

Published: 01/01/2013

DOI:

10.1080/13501763.2013.781802

Document Version:

Publisher's PDF, also known as Version of record

Document license:

Taverne

Please check the document version of this publication:

- A submitted manuscript is the version of the article upon submission and before peer-review. There can be important differences between the submitted version and the official published version of record.

People interested in the research are advised to contact the author for the final version of the publication, or visit the DOI to the publisher's website.

- The final author version and the galley proof are versions of the publication after peer review.

- The final published version features the final layout of the paper including the volume, issue and page numbers.

Link to publication

\footnotetext{
General rights rights.

- You may freely distribute the URL identifying the publication in the public portal. please follow below link for the End User Agreement:

www.umlib.nl/taverne-license

Take down policy

If you believe that this document breaches copyright please contact us at:

repository@maastrichtuniversity.nl

providing details and we will investigate your claim.
}

Copyright and moral rights for the publications made accessible in the public portal are retained by the authors and/or other copyright owners and it is a condition of accessing publications that users recognise and abide by the legal requirements associated with these

- Users may download and print one copy of any publication from the public portal for the purpose of private study or research.

- You may not further distribute the material or use it for any profit-making activity or commercial gain

If the publication is distributed under the terms of Article $25 \mathrm{fa}$ of the Dutch Copyright Act, indicated by the "Taverne" license above, 


\section{Journal of European Public Policy}

\section{Issue salience in the European policy process: what impact on transposition?}

\section{Aneta Spendzharova \& Esther Versluis}

To cite this article: Aneta Spendzharova \& Esther Versluis (2013) Issue salience in the European policy process: what impact on transposition?, Journal of European Public Policy, 20:10, 1499-1516, DOI: 10.1080/13501763.2013.781802

To link to this article: https://doi.org/10.1080/13501763.2013.781802

\section{Published online: 01 May 2013.}

Submit your article to this journal ๘

Џll Article views: 1509

Q View related articles $\asymp$

Citing articles: 21 View citing articles 


\title{
Issue salience in the European policy process: what impact on transposition?
}

\author{
Aneta Spendzharova and Esther Versluis
}

\begin{abstract}
Analyses of agenda setting and decision making have highlighted that issue salience plays an important role in those stages of the policy process. This article investigates the role of issue salience in the implementation stage, focusing on transposition. We examine the extent to which issue salience - the relative importance attached to an issue in relation to others - influences the timeliness of transposing European Union directives in national legislation. We analyse 143 European Union environmental directives adopted in the period 1996-2008 in ten member states. We operationalize issue salience as the salience of hazardous substances and materials, salience for political parties in government and salience for the general public. Our results show faster transposition when environmental issues are salient for the governing political parties, Green political parties are included in the government, and the general public ranks environmental issues as a top priority.
\end{abstract}

KEY WORDS European Union policy process; issue salience; transposition of European Union law.

\section{INTRODUCTION}

Policymakers in all stages of the policy process operate with limited available time and realize that not all policy items can receive the attention they ideally deserve. Thus they tend to focus on a smaller subset of issues that have most attracted their attention. It is exactly this relative importance of an issue that influences policymakers' prioritization and their subsequent actions (Jones and Baumgartner 2005; Oppermann and Viehrig 2011). Issue salience has been employed widely in analyses of voting behaviour, where it helps to account for which issues are discussed or neglected by the candidates in an election campaign as well as how salience influences voters' electoral choices (Opperman and Viehrig 2011; Wlezien 2005). In the public policy literature, issue salience has been analysed most extensively in the agenda-setting stage, where it shapes which items end up on the agenda and which are dismissed (Jones and Baumgartner 2005; Kingdon 1995; Princen 2009).

Scholars seem to agree that salience refers to the relative importance attached to a certain issue in relation to other issues (Borghetto 2008; Oppermann and 
Viehrig 2011; Wlezien 2005). Yet taking stock of the existing body of literature, Oppermann and Viehrig (2011: 272) have concluded that most empirical studies focusing on issue salience as an independent variable 'could neither pin down a clear and distinctive causal impact of issue salience nor rule out such impacts'. Issue salience does not feature as a key determinant of timely compliance with European Union (EU) law in Angelova et al.'s (2012) metaanalysis of 37 scholarly articles on compliance.

While issue salience has not been a topic of intense scholarly debate in the literature on the transposition of European Union (EU) law, several qualitative studies have suggested that it contributes to successful policy implementation. Knill (1997: 11) argued that '[i]f political salience is low, we assume that perception of adaptation pressure shifts from a moderate to a low level'. In other words, governments are likely to be less vigilant about low salience policies and the corresponding legislation is more likely to be 'overlooked, neglected, or taken as being satisfactorily resolved by given administrative arrangements' (Knill 1997: 11). Versluis (2007) demonstrated in a case study of the Safety Data Sheets Directive that the low salience of this topic resulted in a lack of practical application. Bursens and Deforche (2008) have shown that high salience triggers intensive activity of private actors and public authorities, and thus contributes to efficient adaptation. However, issue salience could also produce transposition delay. Dimitrova and Toshkov (2009) found that political salience coupled with domestic opposition leads to inadequate compliance.

This article aims to analyse more systematically different empirical aspects of issue salience. We focus on transposition rather than practical implementation for reasons of data availability. ${ }^{1}$ To begin with, we present important determinants of the pace of transposition identified in the literature and our conceptualization of issue salience. We then discuss the choice of policy sector, case selection and operationalization of variables used in the analysis. We test whether high-risk environmental issues, government salience of environmental issues, presence of a Green party in government, and public opinion speed up the transposition process, controlling for other relevant variables identified in the literature. The article concludes that while issue salience is not the most important factor driving the pace of transposition, it certainly matters. For example, if Green political parties are included in the government, if protecting the environment is highly salient for the government in power and if the general public ranks environmental issues as a top priority, we find evidence of faster transposition of EU environmental directives.

\section{CONCEPTUALIZING THE ROLE OF ISSUE SALIENCE IN TRANSPOSITION}

\subsection{State of the art in transposition research}

With the expansion of the European Union's law-making competences in policy areas such as the common market, environment and social policy, questions 
about the timely transposition and implementation of EU law have become increasingly relevant for decision makers and practitioners both in Brussels and in member state capitals. In the research community, the last decade has been characterized by a growth of transposition studies that investigate the pace and effectiveness of the legal incorporation of $\mathrm{EU}$ directives into national legislation (see, amongst others, Dimitrakopoulos 2001; Haverland et al. 2010; Kaeding 2008; König and Luetgert 2008; Mastenbroek 2003; Thomson et al. 2007; Toshkov 2008; Zhelyazkova and Torenvlied 2009). While the findings concerning some commonly analysed variables are inconclusive, other variables display fairly consistent effects across different studies. What do we know so far? Most analyses test a set of:

1. domestic macro-institutional variables such as constitutional structure and veto players;

2. domestic micro-institutional variables such as administrative capacity, degree of centralization of executive authority, nature and intensity of political actors' preferences, degree of autonomy of the implementing agencies, degree of national discretion, as well as pluralism and corporatism;

3. controls for policy sector and country effects;

4. directive-level factors such as the origin, complexity and topic of the directive, and time available for transposition.

First, macro-institutional variables refer to fundamental domestic institutions that change rarely, such as a state's constitutional structure. In the literature, one such factor - federalism - registers a negative effect in several studies (e.g. Thomson et al. 2007). However, Giulliani (2003) finds no significant effect using Lijphart's index of federalism and Beck's index of regional autonomy respectively. The impact of domestic veto players is even more elusive and different veto player indices lead to conflicting results. Börzel et al. (2007), Mbaye (2001) and Toshkov (2007) find no significant effect using diverse measures such as Huber's 1993 index of political structures and Henisz's index of political constraints. By contrast, Kaeding (2008) finds a negative effect using Schmidt's veto points index and Perkins and Neumayer (2007) find a negative relationship using Henisz's index of political constraints.

Second, among domestic micro-institutional variables, state administrative capacity consistently registers a significant effect. The more efficient the state administrative apparatus, the faster EU directives are transposed (Dimitrakopoulos 2001; Mbaye 2001; Toshkov 2008; Zubek 2005). Regarding the preferences of salient domestic actors, König and Luetgert (2008) used data from national party manifestos to determine actors' preferences. They found that the higher the level of EU conflict, the more legislative actors are involved, and the more qualified-majority voting is applied during the decision-making stage, the more likely it is to observe compliance.

Third, most large-n analyses control for differences in policy sector and country effects. Falkner et al. (2005) argue that the implementation of EU law operates according to three distinct logics in the 'world of law observance', 
the 'world of domestic politics' and 'the world of neglect'. In the world of exemplary compliance, which includes Denmark, Sweden and Finland, the value of compliance with the EU per se overshadows domestic concerns about the specific impact of EU rules. In the world of domestic politics, encompassing Germany, the Netherlands, Spain and the UK, domestic considerations can prevail and transposition is smooth unless there is active resistance from important domestic actors. In the world of neglect, which includes countries such as France, Greece and Portugal, non-compliance with EU law is the rule rather than the exception. A recent update of the typology includes the 'world of dead letters', including Italy, Hungary, Slovakia and other new member states, where transposition may occur on time but the subsequent practical implementation is dubious (Falkner and Treib 2008). A caveat applies here that both the empirical fit and the theoretical underpinnings of this typology have been challenged in the literature (Toshkov 2007).

Fourth, directive-level factors play a strong role in explaining transposition results. A first determinant of timely transposition is the available time (Haverland et al. 2010). The more time is available, the more likely it is that transposition will be completed on time. Secondly, several studies indicate that the type of directive matters. Amending (or modifying) directives are transposed more quickly than new directives, as they 'merely' fill in gaps or add new aspects to existing directives. In addition, Commission directives are more likely to result in timely transposition than Council (and Council and Parliament) directives (Haverland et al. 2010; König and Luetgert 2008; Steunenberg and Kaeding 2009). The latter often cover politically sensitive issues, while Commission directives are usually more technical and thus generate less contestation. ${ }^{2}$ Several authors have shown that the more complex or controversial a directive is, the slower its transposition (König and Luetgert 2008; Steunenberg and Kaeding 2009).

We endorse Steunenberg and Toshkov's (2009) call to include a wide range of factors in comprehensive causal models of transposition (see also Kaeding 2008; Thomson et al. 2007). In this study, issue salience has both a domestic and a directive-level component. Our analysis confirms that the salience of environmental issues differs cross-nationally and over time. We now outline our conceptualization of issue salience and how it could influence the transposition of EU environmental directives.

\subsection{The role of issue salience in transposition}

Defining salience as the relative importance of an issue in relation to other issues remains rather abstract; we need further conceptualization in order to apply it to analysing transposition. The key question here is what determines the "politics of attention' (Jones and Baumgartner 2005). Why do some issues capture the attention of policy actors, and are thus prioritized, whereas others do not? Since decision makers are faced with limited capacity and resources to process information in a given time period, they have to be selective. Salience influences 
the 'attention actors devote to the issue in question' as well as 'the issue's overall prominence in the minds of decision-makers'. It thus refers to 'cognitive shortcuts of human actors to select which information they process before deciding on a course of action' (Oppermann and De Vries 2011: 3-4).

In conceptualizing issue salience, the public policy literature has focused on the relative importance of issues and subsequent prioritization of policy actions. Some issues are considered more urgent and important than others, therefore policymakers focus more attention and resources on dealing with those issues first. Using a somewhat different approach, the public opinion literature has developed sophisticated measures of issue salience as preference intensity. Franklin and Wlezien (1997) have established that in salient domains voters scrutinize politicians' actions and are more likely to express dissatisfaction if a policy does not correspond to their preferences. De Vries (2010) has found that when issues are highly salient for voters, they are more likely to have an impact on the positions of political parties. The preference intensity conceptualization of issue salience has been applied to understanding the actions of policymakers and governments in power (Tatham 2012; Thomson et al. 2012; Veen 2011; Warntjen 2012). This approach is also frequently used in game theoretic models of EU decision making (Häge 2011; Selck 2006). In the end, the public policy and public opinion conceptualizations are complementary. If one knows the intensity of actors' preferences, one can derive a rank-ordering of issues from the most salient to the least salient.

Based on these insights from the literature, we identify three main channels through which we expect issue salience to have an impact in environmental policy. These are the degree of risk involved in regulating certain materials and substances through environmental legislation, the salience of environmental issues for the government in power and the salience of environmental issues for the general public. Below we present four hypotheses in greater detail. We also conducted expert interviews with two Dutch civil servants who are actively involved in the transposition of EU environmental directives to identify plausible causal mechanisms through which issue salience could influence policy outcomes. ${ }^{3}$

To begin with, we examine whether directives regulating the treatment of hazardous materials and dangerous substances are transposed faster than those regulating other issues. The agenda-setting literature has demonstrated that 'focusing events' (Kingdon 1995) determine which problems receive greater visibility and more attention, and thus end up on the agenda. Examples of such 'focusing events' abound: one can think of disasters, external shocks, risks or perceptions thereof, pressure campaigns, political activism, or dissent between relevant policy actors. As Kingdon has illustrated insightfully, '[a]n issue becomes a burning issue when it reaches crisis proportions. Until there's a crisis, it's just one of many issues' (respondent in Kingdon 1995: 95). Focusing events lead to media attention, and this mediatization enhances the salience of an issue (Oppermann and Viehrig 2011). In further conceptualizing the relation between issue salience and transposition, we depart from the assumption that high-risk directives are more likely to trigger 'focusing events' if they are not 
implemented correctly. Thus we examine whether high-risk directives regulating dangerous and hazardous substances are transposed faster.

Hypothesis 1: Directives regulating high-risk issues are transposed faster.

The next two hypotheses focus on the relative importance of environmental issues for political parties in power, departing from the assumption that salience for political parties in power can affect how much they scrutinize incoming legislation from the EU. If environmental issues are highly salient for a cabinet, it may scrutinize EU legislation more carefully to ensure its effective use in the domestic legal system. Thus more transposition delay may occur. An additional strategy to gauge the government salience of environmental issues is to examine whether the presence of Green parties in a coalition government increases the timeliness of transposition. In interviews conducted to identify potential relevant causal mechanisms, civil servants in the Dutch Environmental Ministry indicated that it matters considerably whether the government is 'environmentally friendly'. We anticipate that governments including Green parties will give a higher priority to the transposition of environmental legislation, and act to implement EU legislation on time.

Hypothesis 2: The more salient environmental issues are for a government, the slower the transposition process.

\section{Hypothesis 3: The presence of a Green party in government is associated with faster transposition.}

Finally, we connect issue salience to public opinion. As policymakers are expected to take into account public opinion (Wlezien 2005), we test whether the relative importance of environmental issues for the general public affects a country's transposition record. In our view, when the general public cares about an issue and indicates that it should be tackled as a top priority, there is more pressure on policymakers to act. Public scrutiny of whether sufficient legislation is in place calls for efforts both at the EU level to produce adequate directives and at the national level to transpose EU legislation faster. As our expert interviews suggest, 'when an issue receives a lot of political and social attention, there is an extra effort to do things right'.

Hypothesis 4: The more public opinion supports environmental issues, the faster the transposition process.

\section{POLICY SECTOR, CASE SELECTION AND OPERATIONALIZATION}

\subsection{Policy sector and case selection}

In order to operationalize issue salience and assess its impact on transposition, we focus on EU environmental directives adopted in the period 1996-2008. The scope and depth of EU law-making activities have expanded significantly 
since the official inclusion of this field in the Single European Act (1986). Our 12-year snapshot captures a total of $143 \mathrm{EU}$ directives with varying types, topics and complexity. The choice of starting year, 1996, was determined by the earliest available issue salience data for all ten countries in our sample. The analysis ends in 2008, as most 2008 directives had a 2010 transposition deadline, which still allows us to measure the dependent variable - transposition delay. This was not possible for directives adopted later. This approach will preclude us from comparing the dynamics of transposition across policy sectors, and thus will limit the possibilities for generalization. With this caveat in mind, we have opted for a systematic longitudinal examination of transposition in a policy area where we expect salience to play a role.

In addition to important variation at the directive level, the chosen period of analysis offers important variation in environmental awareness and interest (and thus the salience of environmental topics) in our cases. We examine a subset of the $27 \mathrm{EU}$ member states that includes ten countries, representative of three distinct groups. Denmark, Germany and the Netherlands are selected to represent environmental 'leaders' and are generally expected to complete the transposition process in a timely manner. Greece, Italy and Spain are selected as environmental 'laggards' and are generally expected to complete the transposition of environmental directives slower than the first group of countries. The selection of both 'leaders' and 'laggards' in our sample aims to correct a shortcoming observed by Angelova et al. (2012) that studies on compliance with EU law rarely include both complying Scandinavian states and non-complying southern European states. We also include the United Kingdom as a country with a mixed environmental transposition record that does not fall clearly into either group. Finally, we selected new EU member states from Central and Eastern Europe - Bulgaria, the Czech Republic and Poland. These member states have generally transposed EU environmental legislation on time in order to qualify for accession to the Union. Yet they often show administrative capacity limitations that may hamper full implementation. While these member states joined the Union after much environmental legislation had already been passed, they faced the same challenges as the 'old' member states of transposing existing environmental legislation. Thus, the transposition delay measure used here is meaningful and comparable across all cases. Table 1 summarizes the scale of measurement for all variables in the analysis and the respective data sources.

\subsection{Operationalizing the pace of transposition}

We measure the dependent variable - transposition delay - as the number of days passed after the expiry of the official transposition deadline specified in the EU directive, as reported in the EUR-Lex database. ${ }^{4}$ This empirical strategy is consistent with recent large-n transposition studies (see Steunenberg and Toshkov 2009; Toshkov 2007, 2008; Thomson et al. 2007; Zhelyazkova and Torenvlied 2009). The EUR-Lex database provides the dates for both the earliest and the latest relevant national implementing measure (NIM). We chose 
Table 1 Variables in the analysis

\begin{tabular}{|c|c|c|}
\hline Variable & Measurement & Data source \\
\hline Transposition delay & Days of transposition delay & EUR-Lex database \\
\hline High-risk issue & Dichotomous, $1=$ high risk & $\begin{array}{l}\text { Authors' coding based on } \\
\text { EUR-Lex directive } \\
\text { description }\end{array}$ \\
\hline $\begin{array}{l}\text { Government salience } \\
\text { of environmental } \\
\text { issues }\end{array}$ & $\begin{array}{l}\text { Party manifestos, higher } \\
\quad \text { values }=\text { higher salience }\end{array}$ & Tim Veen (2011) dataset \\
\hline $\begin{array}{l}\text { Green party in } \\
\text { government }\end{array}$ & $\begin{array}{l}\text { Dichotomous, } 1=\text { Green party } \\
\text { in government }\end{array}$ & Authors' coding \\
\hline $\begin{array}{l}\text { Public opinion } \\
\text { salience of } \\
\text { environmental } \\
\text { issues }\end{array}$ & $\begin{array}{l}\text { Percentage interviewed saying } \\
\text { environmental issues should } \\
\text { be a top priority }\end{array}$ & Eurobarometer \\
\hline $\begin{array}{l}\text { Government position } \\
\text { on environmental } \\
\text { issues }\end{array}$ & $\begin{array}{l}\text { Party manifestos, lower values } \\
\text { = emphasis on economic } \\
\text { growth; higher values = } \\
\text { emphasis on environmental } \\
\text { protection }\end{array}$ & Tim Veen (2011) dataset \\
\hline $\begin{array}{l}\text { Bargaining power in } \\
\text { the Council of the } \\
\text { EU }\end{array}$ & $\begin{array}{l}\text { Higher values = more } \\
\text { bargaining power }\end{array}$ & Shapley Shubik index \\
\hline Novelty & $\begin{array}{l}\text { Dichotomous, } 1=\text { amending } \\
\text { legislation }\end{array}$ & EUR-Lex database \\
\hline Scope & Number of reported NIMs & EUR-Lex database \\
\hline Directive type & $\begin{array}{l}\text { Dichotomous, } 1=\text { Commission } \\
\text { directive }\end{array}$ & EUR-Lex database \\
\hline Veto players & $\begin{array}{l}\text { Relevant veto points }(0-4 \\
\text { index) }\end{array}$ & Authors' calculations \\
\hline Corruption-free & $\begin{array}{l}\text { CPI index, range } 1-10 \\
0=\text { highly corrupt; } \\
10=\text { highly clean }\end{array}$ & $\begin{array}{l}\text { Transparency International } \\
\text { from Gothenburg dataset } \\
\text { 'Quality of Government' }\end{array}$ \\
\hline New member state & $\begin{array}{l}\text { Dichotomous, } 1=\text { new EU } \\
\text { member state (BG, CZ, POL } \\
\text { in sample) }\end{array}$ & Authors' coding \\
\hline
\end{tabular}

the latter as our benchmark for calculating transposition delay, because it is a better indicator of complete transposition than the earliest one, which only marks the start of the transposition process.

\subsection{Operationalizing issue salience}

This section presents our operationalization of issue salience, according to the four hypotheses presented earlier. Regarding hypothesis 1, we use the EUR- 
Lex database of keywords indicating whether it deals with a high-risk issue such as 'chemical pollution', 'hazardous substances', 'radioactive substances' and 'dangerous substances'. We then construct a dichotomous variable taking value ' 1 ' for high-risk keywords and ' 0 ' for all other keywords.

With respect to hypotheses 2 and 3, policy documents such as political parties' programmes and manifestos provide us with a window into policymakers' prioritization of relevant issues (see Borghetto 2008). We derive our issue salience measure from Veen's (2011) dataset which uses political party manifestos. Political parties choose to dedicate more space in their manifesto to certain issues in order to signal what they strongly care about. 'The bigger the share of the manifesto's total budget being allocated to a particular policy domain, the more salience an actor attaches to it' (Veen 2011: 278). Yet a caveat is in order: Warntjen (2012) has established that expert interview measures of issue salience are the most nuanced and fine grained. Estimates obtained from expert assessments are not always in line with alternative measurements based on computer-aided text analysis and media coverage. In addition, we examine whether the presence of Green parties in coalition governments increases the timeliness of transposition.

Finally, concerning hypothesis 4, we use Eurobarometer surveys to capture the salience of environmental issues for the general public. The question wording is comparable across time: 'I am going to read out a list of actions that the European Union could undertake. For each one, please tell me if, in your opinion, it should be a priority, or not ... Protecting the environment' (European Commission 1996-2008). We expect that higher public support, measured as the percentage of respondents indicating that the environment should be a top priority, will speed up transposition.

\subsection{Operationalizing the control variables}

In addition to the variables that tap into issue salience discussed above, we have included a set of control variables based on previous studies. While the main focus of our analysis is the effect of issue salience on transposition, we also need to consider the impact of political parties' preferences (König and Luetgert 2008; Thomson et al. 2007; Zhelyazkova and Torenvlied 2009). We use political party positions as a measurable empirical manifestation of preferences. We draw on Veen's (2011) dataset which captures whether party manifestos prioritize economic growth or environmental protection. The position of the governing political party or coalition on the importance of economic growth $v i s-\grave{a}$-vis environmental protection could affect the timeliness of transposing EU directives.

We also consider the effect of power. Member states with more bargaining power in the Council of the European Union could negotiate a legislative outcome that is more preferable from their point of view. As a consequence, they would be more willing to comply with that legislation. We control for the effect of member states' power in decision making using the Shapley 
Shubik index of bargaining power in the Council, calculated based on Bilbao et al. (2000). The index captures the current allocation of qualified majority voting (QMV) votes in the Council, according to which larger member states have more QMV votes (see Cini 2007).

Furthermore, directive-level factors such as novelty, scope and type could influence the pace of transposition as well. We measure the novelty of a directive using a dichotomous variable which indicates whether a directive amends existing legislation or is completely new. The scope of the directive is measured by the number of NIMs necessary for its transposition. Lastly, the directive type measure captures whether we are dealing with a Council or Commission directive. Previous studies have found that amending directives with smaller scope are transposed faster (Haverland et al. 2010; Steunenberg and Kaeding 2009; Toshkov 2007). All directive-level data are available from the EUR-Lex database.

In addition, we control for the institutional structure of countries in our sample. The veto players measure used here is our own index ranging from 0 to 4 , where a higher score means more veto checks such as a strong bicameral system and large coalition governments. Drawing on the literature, the two components of our index are bicameral legislatures and coalition governments. ${ }^{5}$ The findings about the significance of veto players in transposition are contradictory, but in general, more veto players are expected to slow down transposition.

Previous studies have found that a country's administrative capacity influences the speed of transposition. The World Bank quality of government indices are frequently used in the literature as a measure of administrative capacity. However, upon closer inspection, the index provides counterintuitive scores, indicating similar administrative capacity in Spain and Bulgaria, for example. We know from qualitative comparisons of administrative capacity that this is not the case (Dimitrova and Toshkov 2007; Verheijen 2007). Instead, we opted for a proxy measure of administrative capacity using the Transparency International Corruption Perception Index (CPI) from the Gothenburg 'Quality of Government' dataset (Teorell et al. 2010). In line with the literature, we expect that the more corruption is present in a country, the lower the administrative capacity and the slower the transposition process (Heywood and Meyer-Sahling 2008; Meyer-Sahling 2006). Lastly, according to the 'worlds of compliance' argument, Central and Eastern European member states have transposed EU legislation very quickly in order to qualify for EU membership, but the quality of the subsequent implementation is rather poor (Falkner and Treib 2008). Thus we included a dichotomous variable that indicates whether a country is located in Central or Eastern Europe.

\section{TRANSPOSITION OF EU DIRECTIVES: DOES ISSUE SALIENCE PLAY A ROLE?}

Having outlined our conceptualization of issue salience and operationalization strategy, we now turn to discussion of our findings. The empirical observations on the dependent variable - transposition delay - are in line with previous 
results in the literature. Environmental legislation is generally transposed quickly in Denmark, with an average delay of 182 days, and much more slowly in Italy and Greece, with an average delay of 592 and 507 days respectively. Among new EU member states, Bulgaria and the Czech Republic tend to transpose legislation quickly (the average delay is 65 and 113 days respectively), whereas there is more transposition delay in Poland (560 days on average).

Table 2 presents the results of analysing a number of covariates of transposition delay using a Cox Proportional Hazards estimation model. Event history models such as the one employed here are particularly well suited to analysing duration processes in political science, such as the implementation of legislation or cabinet duration (Box-Steffensmeier and Jones 2004; Golub 2007; Toshkov 2010). An individual test of the proportionality assumption regarding each covariate revealed that the effects of a number of the predictors of transposition

Table 2 Cox proportional hazard model estimates of transposition delay in EU environmental policy directives

\begin{tabular}{lll}
\hline Variable & $\begin{array}{c}\text { Hazard } \\
\text { ratio }\end{array}$ & $\begin{array}{c}\text { Corresponding standard } \\
\text { errors }\end{array}$ \\
\hline High-risk issue (low-risk baseline) & 0.98 & $(0.11)$ \\
Government salience of environmental & $1.09^{* * *}$ & $(0.33)$ \\
$\quad$ issues & $0.99^{* * *}$ & $(0.005)$ \\
Government salience $\times$ In(time) & $1.54^{* *}$ & $(0.30)$ \\
Green party in government & $1.02^{*}$ & $(0.01)$ \\
Public opinion salience of environmental & & \\
$\quad$ issues & 1.03 & $(0.18)$ \\
Government position on environmental & & \\
$\quad$ issues & $0.99^{* *}$ & $(0.003)$ \\
Government position $\times$ In(time) & 1.21 & $(3.21)$ \\
Bargaining power in the Council of the EU & $6.18^{* * *}$ & $(3.14)$ \\
Novelty (new directive baseline) & $0.79^{* * *}$ & $(0.07)$ \\
Novelty $\times$ In(time) & $0.72^{* * *}$ & $(0.05)$ \\
Scope & $1.04^{* * *}$ & $(0.01)$ \\
Scope $\times$ In(time) & $1.41^{* *}$ & $(0.21)$ \\
Directive type (Council/European Parliament & & \\
$\quad$ directive baseline) & 0.93 & $(0.05)$ \\
Veto players & $1.20^{* * *}$ & $(0.05)$ \\
Corruption-free & $7.84^{* * *}$ & $(5.48)$ \\
New member state & $0.82^{*}$ & $(0.10)$ \\
New member state $\times$ In(time) & & \\
487 observations & & \\
LR Chi ${ }^{2}$ 149.42*** (17 df) & & \\
\hline
\end{tabular}

Note: The table presents estimated hazard ratios obtained by applying a Cox Proportional Hazards model with standard errors reported in parentheses. The significance levels are as follows: ${ }^{*} p<.10,{ }^{* *} p<.05,{ }^{* * *} p<.01$ 
delay in our model change over time. Therefore, we included time-dependent effects (interactions between the original covariate and the natural logarithm of time) for all predictors that failed the individual proportionality test.

Box-Steffensmeier and Jones (2004: 95) and Bennett (1999: 261) have shown that analysing time-dependent dynamics can help to determine whether processes are likely to die out over time or have a tendency to self-perpetuate. In the first scenario, the data exhibit positive time dependence (the hazard rate increases over time) and it becomes more likely that the phenomenon will end. By contrast, if the data exhibit negative time dependence (the hazard rate decreases over time), the phenomenon self-perpetuates over time. For example, positive time dependence has been observed in enduring rivalries between countries. As time goes by, rivals appear to wear themselves out and become more likely to settle their dispute. Negative time dependence has been observed in labour strikes, which tend to become entrenched as more time passes by (see Bennett 1999: 267-8). We show below that the time-dependent effects in our case reveal processes that die out over time.

Table 2 reports hazard ratios, the exponentiated coefficients, to facilitate the interpretation. In addition, we report a more detailed investigation of the combined time-invariant and time-variant components of time-dependent covariates in Table $3 .^{6}$ Hazard ratios greater than 1 mean that the risk of the event happening (event here means transposition) increases as the values of the variable increase, thus resulting in less transposition delay. By contrast, hazard ratios lower than 1 imply more transposition delay. Hazard ratios approximating 1 mean that the variable has no effect on transposition delay.

Starting with hypothesis 1 , the analysis shows that high-risk issues are associated with slower transposition, which contradicts our initial expectations. At the same time, the effect is very small and not statistically significant. Regarding hypothesis 2, a higher salience of environmental issues for governments in power is initially associated with faster transposition and the effect is highly statistically significant. However, as time goes by, this effect diminishes and beyond 191 days after the deadline, it actually slows down transposition. Thus our hypothesis that high salience of environmental issues slows down transposition is supported, but only after the transposition deadline has passed. The observed switching of the issue salience effect suggests a complex time-dependent dynamic that needs to be investigated more carefully through qualitative analysis.

With respect to hypothesis 3 , we find a highly statistically significant effect confirming that a Green party in government speeds up the transposition of environmental directives. Having a Green party in government increases the hazard of transposition by 54.3 per cent $(\exp (0.434)-1)$. Lastly, the analysis also confirms hypothesis 4 . We find that favourable public opinion is associated with faster transposition of environmental directives and the effect is statistically significant, but substantively very small.

Let us now turn to the control variables. Starting with government preferences, we find that if a government prioritizes the environment over economic 
Table 3 The impact of time-dependent effects

\begin{tabular}{lcccccc}
\hline & -0.50 & -0.25 & Mean & +0.25 & +0.50 & +1.00 \\
Days of delay & 62 & 191 & 320 & 449 & 579 & 837 \\
\hline Government salience of & 0.020 & 0.003 & -0.005 & -0.010 & -0.013 & -0.019 \\
$\quad$ environmental issues & & & & & & \\
s.e. & $(0.024)$ & $(0.026)$ & $(0.027)$ & $(0.028)$ & $(0.029)$ & $(0.030)$ \\
p-value & $\mathbf{0 . 4 0 8}$ & $\mathbf{0 . 8 9 9}$ & $\mathbf{0 . 8 6 7}$ & $\mathbf{0 . 7 3 2}$ & $\mathbf{0 . 6 4 4}$ & $\mathbf{0 . 5 3 1}$ \\
Government position on & 0.002 & -0.005 & -0.008 & -0.010 & -0.011 & -0.013 \\
$\quad$ environmental issues & & & & & & \\
s.e. & $(0.010)$ & $(0.010)$ & $(0.010)$ & $(0.010)$ & $(0.011)$ & $(0.011)$ \\
p-value & $\mathbf{0 . 8 3 0}$ & $\mathbf{0 . 6 5 4}$ & $\mathbf{0 . 4 5 7}$ & $\mathbf{0 . 3 5 7}$ & $\mathbf{0 . 2 9 8}$ & $\mathbf{0 . 2 3 0}$ \\
Novelty (new directive & 0.863 & 0.603 & 0.482 & 0.403 & 0.345 & 0.260 \\
$\quad$ baseline) & & & & & & \\
s.e. & $(0.201)$ & $(0.167)$ & $(0.171)$ & $(0.179)$ & $(0.189)$ & $(0.206)$ \\
p-value & $\mathbf{0 . 0 0 0}$ & $\mathbf{0 . 0 0 0}$ & $\mathbf{0 . 0 0 5}$ & $\mathbf{0 . 0 2 5}$ & $\mathbf{0 . 0 6 7}$ & $\mathbf{0 . 2 0 8}$ \\
Scope & -0.170 & -0.125 & -0.104 & -0.091 & -0.081 & -0.066 \\
s.e. & $(0.044)$ & $(0.038)$ & $(0.035)$ & $(0.034)$ & $(0.034)$ & $(0.033)$ \\
p-value & $\mathbf{0 . 0 0 0}$ & $\mathbf{0 . 0 0 1}$ & $\mathbf{0 . 0 0 3}$ & $\mathbf{0 . 0 0 8}$ & $\mathbf{0 . 0 1 7}$ & $\mathbf{0 . 0 4 8}$ \\
New member state & 1.213 & 0.987 & 0.881 & 0.813 & 0.762 & 0.688 \\
s.e. & $(0.318)$ & $(0.290)$ & $(0.298)$ & $(0.309)$ & $(0.321)$ & $(0.341)$ \\
p-value & $\mathbf{0 . 0 0 0}$ & $\mathbf{0 . 0 0 1}$ & $\mathbf{0 . 0 0 3}$ & $\mathbf{0 . 0 0 9}$ & $\mathbf{0 . 0 1 7}$ & $\mathbf{0 . 0 4 4}$ \\
\hline
\end{tabular}

Note: The presented coefficient estimates are $\beta_{t}=\beta_{1}+\beta_{2} \times \ln (t)$, where $\beta_{1}$ is the time-independent coefficient for a covariate, $\beta_{2}$ is the time-dependent coefficient, and $\ln (\mathrm{t})$ is the natural logarithm of time. The corresponding standard errors are reported underneath in brackets. The presented p-values are based on the Wald statistic, which follows a $\chi^{2}$ distribution. Coefficient estimates are in italics if $p<$ 0.05 . Time is presented in the first row as standard deviations from the mean of transposition delay; the second row reports the corresponding days of delay. We do not analyse -025 s.d. below the mean of transposition delay, as this is less than 0 days of delay.

growth, it transposes EU environmental directives faster. However, the effect is very small, not statistically significant, and diminishes over time. Similarly, member states with more bargaining power in the Council transpose EU directives faster, but the effect is not statistically significant. By contrast, directive-level variables such as novelty and scope register very strong and statistically significant effects. Amending legislation is transposed faster than new legislation and the effect is highly statistically significant. At 62 days of delay the transposition hazard of amending legislation is 137 per cent (exp(0.863)-1) higher than that of new directives. This is probably due to the fact that amending acts supplement existing legislation and do not require extensive preparation of new laws domestically. Yet the effect diminishes over 
time both in magnitude and significance and is no longer statistically significant after 579 days of delay, when the transposition hazard for amending directives is higher by 41.2 per cent $(\exp (0.345)-1)$.

The analysis confirms that the more national implementing measures are necessary to transpose a piece of legislation, the lengthier the transposition process. The effect is strong and statistically significant even after 837 days of delay. This could be explained by the greater attention and resources required to scan and plan the necessary adjustments of the existing domestic legal framework. We also find that Commission directives are transposed faster in the national legal framework than Council ones and the effect is statistically significant. Having more veto point constraints such as a strong bicameral system and a very large coalition government has the expected effect in our model: it slows down transposition, but the effect is not statistically significant.

Our proxy measure for the quality of government and public administration - an index of how corruption-free a country is - registers a highly statistically significant effect. Countries with lower levels of corruption transpose EU environmental legislation faster than countries with higher levels of corruption. Finally, we also control for the so-called 'world of dead letters' effect of having three Central and Eastern European member states in our sample (Falkner and Treib 2008). Indeed, our analysis shows that new EU member states transpose EU environmental legislation faster and the result is highly statistically significant. At 62 days after the deadline, the transposition hazard for new member states is higher by 236.4 per cent $(\exp (1.213)-1)$. The magnitude and statistical significance of the effect, however, diminish over time and at 837 days of delay the transposition hazard for new member states is higher by 98.9 per cent $(\exp (0.688)-1)$.

\section{CONCLUSION}

This article attempted to conceptualize issue salience and test its influence on the transposition of EU environmental directives in ten EU member states. We analysed a set of 143 environmental policy directives adopted in the period 1996-2008 and established that the strongest determinants of fast transposition are directive-level characteristics, how corruption-free a country is and whether a country is a new EU member state from Central and Eastern Europe. The results suggest that once institutional channels for the incorporation of EU law into national law have been set up, further transposition of amending legislation runs quite smoothly. An efficient administrative apparatus, measured here as a corruption-free system, also speeds up transposition.

We conceptualized issue salience as the relative importance of one issue vis- $\grave{a}$ vis others and operationalized what we consider to be its main components relevant for the transposition of environmental directives - salience of directives regulating high-risk materials, salience for political parties in government and salience for the general public. We found that Green parties in government speed up the transposition process and so does public opinion assigning a top 
priority to environmental issues. High salience of environmental issues for a government initially speeds up transposition, but we found that this effect diminishes over time and 191 days after the deadline, it actually slows down transposition.

This article confirms recent findings in the literature about the presence of time-dependent effects (Haverland et al. 2010; Steunenberg and Kaeding 2009; Zhelyazkova and Torenvlied 2009). The effects of the strongest predictors of fast transposition in our analysis, such as amending directive and smaller directive scope, diminish as time goes by, and certainly after the expiration of the transposition deadline. This is evidence of time-dependent processes that die out over time. In our view, further quantitative - and also qualitative analyses are necessary in order to understand better how and why the effects of important predictors of transposition delay change over time.

Biographical notes: Aneta Spendzharova is Assistant Professor of Political Science at Maastricht University, The Netherlands. Esther Versluis is Associate Professor of European Regulatory Governance at Maastricht University, The Netherlands.

Addresses for correspondence: Aneta Spendzharova, Department of Political Science, Maastricht University, PO Box 616, 6200 MD, Maastricht, The Netherlands. email: a.spendzharova@maastrichtuniversity.nl/Esther Versluis, Department of Political Science, Maastricht University, PO Box 616, 6200 MD, Maastricht, The Netherlands. email: e.versluis@maastrichtuniversity.nl

\section{ACKNOWLEDGEMENTS}

Andreas Lachenmaier provided outstanding research assistance, for which we are very grateful. The authors would also like to thank the participants and discussant Dimiter Toshkov of the panel 'The Implementation of European Law' at the ECPR General Conference in Potsdam (September 2009), as well as the participants and discussant Natalia Timus of the FASoS 'Politics and Culture in Europe' colloquium in Lisbon (June 2010) for their valuable comments. In addition, we thank Asya Zhelyazkova and Lucie Spanihelova for their thoughtful feedback on earlier versions of the article. We also thank the JEPP referees for their helpful comments.

\section{NOTES}

1 The literature distinguishes between 'formal' or 'legal' implementation, which refers to updating the existing laws on the books, and 'practical' or 'administrative' implementation, which taps into the actual enforcement and use of the transposed legal instruments. We only have sufficient data to investigate 'legal' implementation, namely the transposition of EU environmental directives into national legislation.

2 Although Commission directives are generally speaking transposed faster, this does not tell us much about practical implementation. A case study of the practical 
implementation of Commission directive 91/155/EEC on Safety Data Sheets shows uncomplicated transposition (albeit late) but lacking practical implementation (see Versluis 2007).

3 Interview with two civil servants at the Ministry of Infrastructure and the Environment, The Hague, The Netherlands, 29 June 2011.

4 EUR-Lex, although widely used in the literature, is based on self-reported data compiled by member states' administrations. Thus we cannot rule out the possibility of bias in the self-reported estimates of transposition timeliness.

5 We opted for constructing our own veto players index because existing indices do not cover all cases for the entire time period. Our index is weakly positively correlated with standard ones such as the Henisz index of political constraints (Spearman's rho 0.353 ).

6 The reported coefficient estimates in Table 3 are $\beta_{t}=\beta_{1}+\beta_{2} \times \ln (t)$, where $\beta_{1}$ is the time-independent coefficient for a covariate, $\beta_{2}$ is the time-dependent coefficient, and $\ln (\mathrm{t})$ is the natural logarithm of time. The corresponding standard error of this term is calculated according to the formula:

$$
\text { s.e. } \beta \mathrm{t}=\sqrt{\operatorname{var}\left(\beta_{1}\right)+(\ln (\mathrm{t}))^{2} \times \operatorname{var}\left(\beta_{2}\right)+2 \times \ln (\mathrm{t}) \times \operatorname{cov}\left(\beta_{1}, \beta_{2}\right)}
$$

\section{REFERENCES}

Angelova, M., Dannwolf, T. and König, T. (2012) 'How robust are compliance findings? A research synthesis', Journal of European Public Policy 19(8): 1269-91.

Bennett, S. (1999) 'Parametric models, duration dependence, and time-varying data revisited', American Journal of Political Science 43(1): 256-70.

Bilbao, J.M., Fernández, J.R., Jiménez Losada, A. and López, J.J. (2000) 'Generating functions for computing power indices efficiently', available at http://hercules.us. es/ mbilbao/pdffiles/generat.pdf, accessed 6 November 2012.

Börzel, T., Dudziak, M., Hofmann, T., Panke, D. and Sprungk, C. (2007) 'Recalcitrance, inefficiency and support for European integration. Why member states do (not) comply with European law', CES Working Paper, Cambridge, MA: Harvard University.

Borghetto, E. (2008) 'The timely transposition of EU directives in Italy. Do political priorities matter?', Paper presented at the ECPR Joint Sessions of Workshops, Rennes, 11-16 April.

Box-Steffensmeier, J. and Jones, B. (2004) Event History Modeling. A Guide for Social Scientists, Cambridge: Cambridge University Press.

Bursens, P. and Deforche, J. (2008) 'Europeanization of subnational polities: the impact of domestic factors on regional adaptation to European integration', Regional and Federal Studies 18(1): 1-18.

Cini, M. (2007) European Union Politics, Oxford: Oxford University Press.

De Vries, Catherine E. (2010) 'EU issue voting; asset or liability: how European integration affects parties' electoral fortunes', European Union Politics 11(1): 89-117.

Dimitrakopoulos, D. (2001) 'Learning and steering: changing implementation patterns and the Greek central government', Journal of European Public Policy 8(4): 604-22.

Dimitrova, A. and Toshkov, D. (2007) 'The dynamics of domestic coordination of EU policy in the new member states: impossible to lock in?' West European Politics 30(5): 961-86.

Dimitrova, A. and Toshkov, D. (2009) 'Post-accession compliance between administrative co-ordination and political bargaining', European Integration Online Papers 13(19), available at http://eiop.or.at/eiop/texte/2009-019a.htm 
European Commission (1996-2008) 'Standard Eurobarometer. Public opinion in the European Union', available at http://ec.europa.eu/public_opinion/archives_en.htm, accessed 12 May 2010.

Falkner, G. and Treib, O. (2008) 'Three worlds of compliance or four? The EU-15 compared to new member states', Journal of Common Market Studies 46(2): 293-313.

Falkner, G., Treib, O., Hartlapp, M. and Leiber, S. (2005) Complying with Europe? The Impact of EU Minimum Harmonisation and Soft Law in the Member States, Cambridge: Cambridge University Press.

Franklin, M. and Wlezien, C. (1997) 'The responsive public: issue salience, policy change, and preferences for European unification', Journal of Theoretical Politics 9: 347-63.

Giulliani, M. (2003) 'Europeanization in comparative perspective: institutional fit and national adaptation', in K. Featherstone and C. Radaelli (eds), The Politics of Europeanization, Oxford: Oxford University Press, pp. 134-55.

Golub, J. (2007) 'Survival analysis and European Union decision-making', European Union Politics 8: 155-79.

Häge, F.M. (2011) 'Politicising Council decision-making: the effect of European Parliament empowerment', West European Politics 34(1): 18-47.

Haverland, M., Steunenberg, B. and Van Waarden, F. (2010) 'Sectors at different speeds: analyzing transposition deficits in the European Union', Journal of Common Market Studies 48(5): 1-27.

Heywood, P. and Meyer-Sahling, J.H. (2008) Corruption Risks and the Management of the Ministerial Bureaucracy in Poland, Warsaw: Ernst \& Young Better Government Programme.

Jones, B. and Baumgartner, F. (2005) The Politics of Attention. How Government Prioritizes Problems, Chicago: The University of Chicago Press.

Kaeding, M. (2008) 'Lost in translation or full steam ahead: the transposition of EU transport directives across member states', European Union Politics 9: 115-43.

Kingdon, J.W. (1995) Agendas, Alternatives, and Public Policies, New York: Harper Collins.

Knill, C. (1997) 'Implementing European policies: the impact of national administrative traditions', EUI Working Papers 97756.

König, T. and Luetgert, B. (2008) 'Troubles with transposition? Explaining trends in member-state notification and the delayed transposition of EU directives', British Journal of Political Science 39: 163-94.

Mastenbroek, E. (2003) 'Surviving the deadline. The transposition of EU directives in the Netherlands', European Union Politics 4(4): 371-95.

Mbaye, H.A.D. (2001) 'Why national states comply with supranational law. Explaining implementation infringements in the European Union, 1972-1993', European Union Politics 2(3): 259-81.

Meyer-Sahling, J.H. (2006) 'The rise of the partisan state? Parties, patronage and the ministerial bureaucracy in Hungary', Journal of Communist Studies and Transition Politics 22(3): 274-97.

Oppermann, K. and De Vries, C. (2011) 'Analysing issue salience in international politics: Theoretical foundations and methodological approaches', in K. Oppermann and H. Viehrig (eds), Issue Salience in International Politics, London: Routledge, pp. 3-22.

Oppermann, K. and Viehrig, H. (eds) (2011) Issue Salience in International Politics, London: Routledge.

Perkins, R. and Neumayer, E. (2007) 'Do membership benefits buy regulatory compliance? An empirical analysis of EU directives 1978-99', European Union Politics 8(2): 180-206. 
Princen, S. (2009) Agenda-Setting in the European Union, Basingstoke and New York: Palgrave Macmillan.

Selck, T.J. (2006) 'The effects of issue salience on political decision-making', Constitutional Political Economy 17(1): 5-13.

Steunenberg, B. and Kaeding, M. (2009) “"As time goes by”: explaining the transposition of maritime directives', European Journal of Political Research 48: 432-54.

Steunenberg, B. and Toshkov, D. (2009) 'Comparing transposition in the 27 member states of the EU: the impact of discretion and legal fit', Journal of European Public Policy 16(7): 951-70.

Tatham, M. (2012) 'You do what you have to do? Salience and territorial interest representation in EU environmental affairs', European Union Politics 13(3): 434-50.

Teorell, J., Charron, N., Samanni, M., Holmberg, S. and Rothstein, B. (2010) 'The Quality of Government dataset, version 27 May10', Gothenburg: The Quality of Government Institute, University of Gothenburg, available at http://www.qog.pol. gu.se, accessed 15 February 2011.

Thomson, R. et al. (2012) 'A new dataset on decision-making in the European Union before and after the 2004 and 2007 enlargements (DEUII)', Journal of European Public Policy 19(4): 604-22.

Thomson, R., Torenvlied, R. and Arregui, J. (2007) 'The paradox of compliance: infringements and delays in transposing European Union directives', British Journal of Political Science 37: 685-709.

Toshkov, D. (2007) 'In search of the worlds of compliance: culture and transposition performance in the European Union', Journal of European Public Policy 14(6): 933-59.

Toshkov, D. (2008) 'Embracing European law: compliance with EU directives in Central and Eastern Europe', European Union Politics 9(3): 379-402.

Toshkov, D. (2010) 'Taking stock: a review of quantitative studies of transposition and implementation of EU law', Institute for European Integration Research Working Paper 1/2010, Vienna: Institute for European Integration Research, available at http:// eif.univie.ac.at/downloads/workingpapers/wp2010-01.pdf

Veen, T. (2011) 'Positions and salience in European Union politics: estimation and validation of a new dataset', European Union Politics 12(2): 267-88.

Verheijen, T. (2007) 'Administrative capacity in the new EU member states: the limits of innovation?', World Bank Working Paper No. 115.

Versluis, E. (2007) 'Even rules, uneven practices: opening the 'black box' of EU law in action', West European Politics 30(1): 50-67.

Warntjen, A. (2012) 'Measuring salience in EU legislative politics', European Union Politics 13(1): 168-82.

Wlezien, C. (2005) 'On the salience of political issues: the problem with "most important problem"', Electoral Studies 24: 555-79.

Zhelyazkova, A. and Torenvlied, R. (2009) 'The time-dependent effect of conflict in the Council on delays in the transposition of EU directives', European Union Politics 10(1): 35-62.

Zubek, R. (2005) 'Complying with transposition commitments in Poland: collective dilemmas, core executive and legislative outcomes', West European Politics 28(3): 592-619. 